R. SANG, P. KUCMIERCZYK, R. DÜHREN, R. RAZZAQ, K. DONG, J. LIU, R. FRANKE*, R. JACKSTELL, M. BELLER* (EVONIK PERFORMANCE MATERIALS GMBH, MARL, RUHRUNIVERSITÄT, BOCHUM, AND UNIVERSITÄT ROSTOCK, GERMANY)

Synthesis of Carboxylic Acids by Palladium-Catalyzed Hydroxycarbonylation Angew. Chem. Int. Ed. 2019, 58, 14365-14373.

\title{
Palladium-Catalyzed Synthesis of Carboxylic Acids
}
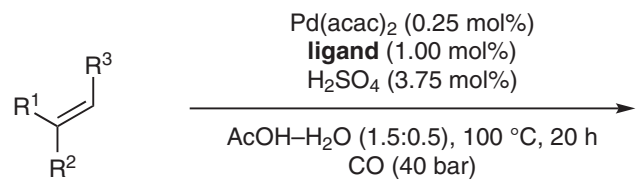

(1.0 equiv)

$R^{1}, R^{2}, R^{3}=H, A l k, A r$

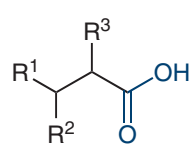

$>40$ examples up to $99 \%$ yield<smiles>CC(C)(C)P(Cc1ccccc1CP(c1ccccn1)C(C)(C)C)c1ccccn1</smiles>

Selected examples:<smiles>C=CCCC(=O)O</smiles>

$99 \%$ yield<smiles>CC(C)=C(C)C</smiles>

$99 \%$ yield n/iso > 99:1<smiles>C=C(C)c1ccc(F)cc1</smiles>

$99 \%$ yield $n /$ iso $>99: 1$

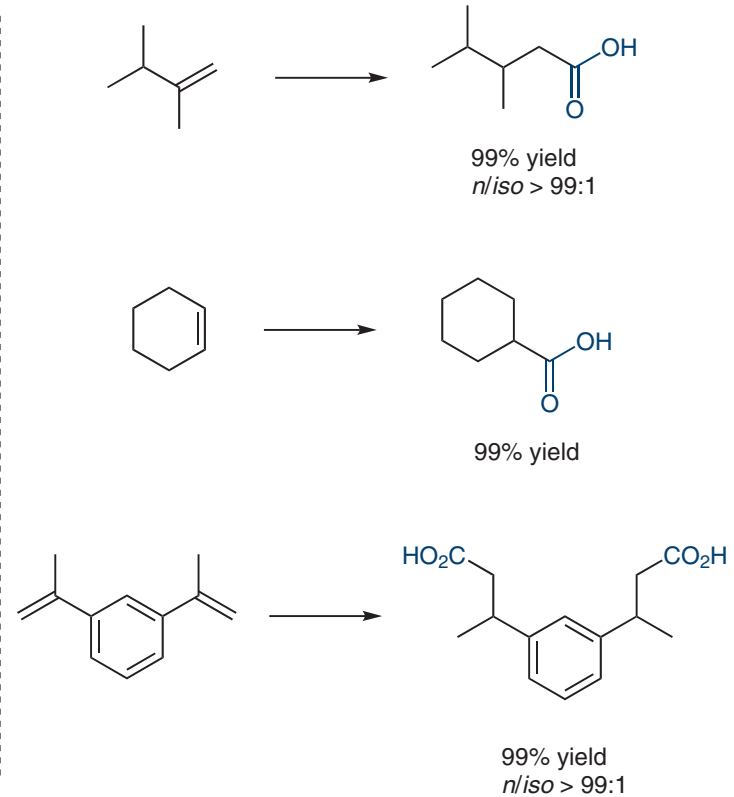

\section{Category}

Metals in Synthesis

\section{Key words}

carboxylic acids

palladium catalysis

hydroxy-

carbonylation
Significance: The authors report a very general and high yielding palladium-catalyzed synthesis of carboxylic acids, starting from alkenes. The method is performed in aqueous environment and uses only $0.25 \mathrm{~mol} \%$ of $\mathrm{Pd}(\mathrm{acac})_{2}$. High pressured carbon monoxide is used as ' $\mathrm{CO}$ ' source, ensuring a good atom economy.
Comment: Various substituted alkenes (over 40 examples) have been successfully transformed into their corresponding carboxylic acids. The method provides the product in high $n /$ iso ratio and can tolerate highly reactive functional groups, such as ketones or phosphates. 